\title{
Changes in the category "the choice of content of philologists training"
}

\section{CHANGES IN THE CATEGORY \\ "THE CHOICE OF CONTENT OF PHILOLOGISTS TRAINING"}

\section{Rubinska Bronislava ${ }^{1}$}

DOI: http://dx.doi.org/10.30525/978-9934-571-27-5_42

Abstract. The category "content of training" is closely connected with another category "content of education", the inalienable part of which is "the choice of the content of philologists training" on the basis of activities and competency-oriented approach. Finding out the new ways of solving the research problem in conditions of modern education reform that takes place in Ukraine we directly connect it with the solution of strategic tasks of Ukrainian education in the context of Bologna process requirements

The question of the activities approach to the choice of content of training for teaching students of humanities profile has been researched on three analysis levels: macro, medium and micro. New technologies have also changed the content of training, so one of the most popular platforms - Kahoot has been analyzed and its content of training evaluated from the point of view of its possibility to provide all of the spheres, forms functions and types of students' communication. In Kahoot platform it's nearly the same, but the contingent of students is much wider. It supports as many different types of learners as possible. The notion "sphere of communication" is different from the notion 'theme', which characterizes line segment of reality without any dependence on the speaker [25]. We consider theme as a structural element of the situation, defining the subject of conversation [21]. We have also given short review of functions of communication.

The third characteristics of communication is closely connected with the first two ones. For socially-oriented communication the most typical speech forms are extended monologues and for person-to-person communication a dialogue, for group communication - a group dialogue(polylogue).

The analysis on the micro level is connected with the distinction of elementary units of speech communication, coupled speech acts of partners

\footnotetext{
${ }^{1}$ Associate Professor of the Romance and Germanic Languages and Translation Chair, National University of Life and Environmental Sciences of Ukraine, Ukraine

(C) Rubinska Bronislava
} 


\section{Rubinska Bronislava}

in communication, forming a cycle, in other words one step acts of speech interaction.

The example of how the results of research were taken into consideration, when writing content of programs (in the part where general and subject specific skills and competencies are described) for teaching students of humanities profile, has been given.

\section{Introduction}

In conditions of stable informational society development higher education qualifications show tendency to lose their actual value within short period of time. The necessity to renew the level of professional training in any sphere of life turns into a must, as far as the generic and subject specific competencies totalities are concerned. Life Long Learning is a means of improving competencies totalities, which shows signs of the XXI century personality's professionalism [24, 27]. To realize such learning and make it more effective is possible on condition one creates renewed basis for the essence of the category "content of training" in this research. This category is closely connected with another category "content of education", the inalienable part of which is the choice of the philologist's content of training on the basis of activities and competency-oriented approach. Many researchers think that the idea of competency is the idea of an open order on content of education [14]. That's why it is necessary to clarify and specify this category from the positions of educational activity. "Educational activity turning into research activity becomes the object of research... It is competency approach that teaches a student to learn" [14]. We agree with those scientists that consider it to be a complex phenomenon which includes not only activity itself but also personal attitude to it and to the subject of activity, including personal and subject-oriented. Finding out the new ways of solving the research problem in conditions of modern education reform that takes place in Ukraine we directly connect it with the solution of strategic tasks of Ukrainian education in the context of Bologna process requirements (worked out by Alexia, B. Bokut, Ya. Balubash, I. Zyazun, L. Kondrashowa, V. Kremen, N. Kuzina, Z. Kurland, O. Molibog, N. Nychkalo and others), priorities aim in training future highly qualified specialist, who is able to participate in joint activities (worked out by M. Bakhtin, O. Leontief, Z. Kornayeva, I. Bym and others). 


\section{Changes in the category "the choice of content of philologists training"}

\section{The research problem}

The improvement of the content of training students who study foreign languages in higher education is connected with more successive usage of activities approach in teaching. Students' activities are much more variable now. After Ukraine entered the EU system of education and has been participating in Bologna process students were given an opportunity to study abroad, participate in international projects, conduct scientific research and report about its results at the international conferences and symposiums. But our analysis has shown that bachelors and masters have certain difficulties in communication in some spheres, including scientific one. So, one of the reasons is that the question of what to teach hasn't been fully researched.

We would like to analyze the research and publications of scientists on the choice of content of training students who study foreign languages. It has been researched by a lot of scientists in Ukraine, Russia, Belorussia and abroad. Such researchers as Y.I. Passov, V.L. Skalkin, N.S, Doroshenko, Z.V., Kornayeva, R.V. Fastovets, I.L. Bim, L.A. Karimova, O.I. Zhdanko and many others $[3,5,6,9,10,19,22,28]$ have written research articles, dissertations and books on it. But the problem of the integration of new principles and other constitutive elements of this category hasn't been fully researched yet.

The aim of this article is to show how communication activities approach and new technologies have changed the content of training for the students, who study in humanitarian universities and "construction of content of training of foreign languages". "How we learn is as important as what we learn, and the way we're learning about our world and participating in it has changed fundamentally." [7]. We have set ourselves the following tasks:

1.to consider the notion "content of training";

2.to study students' communication on three levels;

3.to characterize integration of new principles of choice in new technological platform Kahoot from the point of view of their possibility to provide all of the spheres, forms and types of students' communication;

4.to show the example of how the results of research were taken into consideration, when writing content of programs (in the part where general and subject specific skills and competencies are described) for teaching students of humanities profile. 


\section{Rubinska Bronislava}

\section{Content of training}

Let us first consider the notion "content of training". There is no unanimity in the definition of this notion. According to the authors of the book "Content of Training Foreign Languages at School" there is no unanimous answer to the question "What to teach?" [10]. Using as a basis pedagogical principles and communication theory Mironova T. Y. gave the following interpretation of the term: "construction of content of training of foreign languages, which is aimed at peculiarities of communication and surely corresponds to the demands of modern society. So, it is necessary not only to investigate general problems of communication but also communication of every concrete group of communicating people" $[15,51]$. This understanding of the term was used in our research of the communication of students who study in the faculty of humanities.

\section{Analysis of communication}

The analysis of research papers and books in Psychology showed us that communication is a very complex phenomenon with a hierarchal structure and building. Psychologists analyze communication on three levels: highest(macro), medium(mezzo) and lowest (micro). Such approach allowed us to consider students' activities on the level of activity, detailed actions and separate associated actions, to find out their immanent characteristics and advance to the new elements in the content of training.

Besides, the fact that we live in the society with new technologies which influence the process of communication, made it necessary to analyze one of the popular teaching platform - Kahoot. In it the concept 'content of training and "methods of teaching are integrated together" and only two principles of the choice what to teach are taken into account: self-guided and inquiry-based learning.

So, we will start our analysis with macro level. Here we were mostly interested in communication of students with other people that can be characterized by most typical themes and spheres of communication. The notion "sphere of communication" is also understood differently. Psychology, Linguistics and Methods of Teaching Foreign Languages at Higher School look at this notion from their own professional point of view. We will base our research on the proposed definition by V.L. Skalkin [22] as it is defined on the basis of another notion "situation". Under sphere of communication he understands a whole set of situations. He distinguishes such spheres as: 
social and domestic sphere, family, professional, socio-cultural, sphere of social activity, law and administration sphere, spectacular-mass sphere. It is not explicitly expressed but we can implicitly correlate this nomenclature with practice and intellectual activity of communicators. That's why it is possible to consider spheres of communication via students' activities, in its wide sense, we mean their leading type of activity - studying and scientific work. No matter which of the definitions we choose in the sphere of oral communication a student is the subject of activity, the center of this space. In Kahoot platform it's nearly the same, but the contingent of students is much wider. It supports as many different types of learners as possible. The roles in the situation such as learner, player, researcher, creator, teacher and leader have been chosen to play in the classroom and beyond it. This peculiarity of the notion "sphere of communication" differs it from the notion 'theme', which characterizes line segment of reality without any dependence on the speaker [25]. That's why if we want to provide active position of a student in speech activity we will proceed from the notion 'sphere of communication', but not theme. We consider theme as a structural element of the situation, defining the subject of conversation [21]. Another aspect of our research is the study of functions of communication. It will help to present the planned result of schooling as an ability to realize the main functions of communication. In communication theory the following functions are distinguished: informational-communicative, regulatory-communicative, affective-communicative.

We continued our analysis on the medium (mezzo) level of analysis. Our aim was to research typical students' contacts within the chosen spheres. To solve the problem, we have to consider typological characteristics of communication. They are: types, functions and forms of communication. In real life communication all of them are represented. In classroom communication we can plan one of them as the leading one, also taking into account the stage of education. We considered each of the typological characteristics separately, but in interaction with each other. It has made our analysis integrative.

It is well known in modern Psychology that there are different types of communication: socially-oriented, subject-oriented and interpersonal [12]. All of them are typical for the students of humanities universities. For socially-oriented communication the most typical activities are making speeches in front of the public, delivering reports and short speeches, which 


\section{Rubinska Bronislava}

can be made both in native and in foreign language. But mostly people use foreign language for establishing business and scientific contacts with foreigners. So, during classroom activities students have to be involved in such kind of activities. If we want to bring the process of education closer to the needs of real life communication we should involve students in such situations, where they must act as a subject of communication, be its initiators and organizers in the process of interaction with other participants of activities. It means that we have to consider the choice of content of training taking into account socially-oriented and group-oriented types of communication, their functions, forms and types.

Group-oriented communication is communication in the process of joint activities, which caters for its needs, helps to organize them and solves the aims set. For MAs participation in joint activities is connected with their studies, participation in joint projects and scientific seminars, webinars, conferences and symposiums. They have to search for information and act as a learner, using different gadgets in the role of a researcher. After that they interact with their scientific supervisor as a creator. During their studies they also perform the role of a teacher and a leader, organizer of teaching-learning process, using different methods, including games. At this stage Kahoot games are part of it, integration principle means the choice of content and method of training simultaneously.

\section{The principle of integration}

Let us make analysis of this principle in detail as it is one of the newest included into the category under consideration. The most systemic analysis of this term in Pedagogics was made by Puck M. S. [18; 189-190]. "In the pedagogical literature there are publications in which pedagogical, didactic and methods aspects of the problem of integration and differentiation in education and subject training. Different questions are being considered in them:

- integration processes, involving education sphere and having positive influence on the development of pedagogical science and integration of its functions(Z.A. Mulkovaya, N.D. Nikundrov, B.S. Gershunskiy, V.S. Shubinskiy and others);

- the necessity to reflect the processes of integration in education, taking place in science (A.P. Belyaeva, V.N. Fedorova, I.D. Zverev, V.N. Maximova and others); 


\section{Changes in the category "the choice of content of philologists training"}

- integration processes in innovative pedagogical experience and their influence on the decision of the solution of the problem of harmonizing education(G.F. Fyodore);

- methods of finding out and describing integration processes in educational process (Yu.S. Tunikov, M.S. Puck);

- necessity to integrate content of professional-technical science education, professional-technical education and professional-technical training of (A.P. Belyaeva, M.N. Berulava);

- integration between educational process and scientific research in the system of higher education (V.S. Kabackov, M.S. Puck, G.N. Fadeyev);

- taking away a lot of subjects and raising effectiveness of educational process via integration of educational subjects and disciplines (I.Yu.Alexashina, Yu.K. Dik, A.A. Pynskiy, V.P. Solomin, V.V. Usanov and others.);

- contradictions, regularities and provisions that determine integration processes, sources and mechanisms of interaction, principles and types of integration in science education (A.P. Belyaeva, B.N. Burulava, L.F. Keyrun, Yu.S. Tyunnikov, M.S. Puck and others).

- perestroika of pedagogical thinking on the basis of integration ideas and humanization (A.P. Belyaeva, V.G. Razumovskiy, L.V. Tarasov, I.M. Titova and others)". We agree with her idea that it is reasonable to differentiate such components of integration as: 1) notions, which directly include integration (for example, integrative activities, integrative work);

2) notions, which express vertical structure of the integration notional space (integration between subjects, fund mentalization, interconnection, interaction, interpenetration and others);

3) notions which reflect horizontal structure of the integration notional space (intracycle integration, inner subject integration, levels of integration, facts, notions, methods, language, laws, theories, local nature picture, connection, system) [18; 190-191]. We will base our analysis on such understanding in our further analysis.

\section{Subject-oriented communication}

In psychological articles it is stated that subject-oriented communication is not well researched. But we can ground our research on such characteristics as:

1) joint aim, which unites efforts of participants of joint subject-oriented activity; 


\section{Rubinska Bronislava}

2)the existence of common goal defines and differentiates concrete tasks of each of its participants. It is made concrete in certain tasks entrusted on each participant, and can be realized only in line with joint actions;

3)speech acts(SA), which are realized by the participants of joint activities, are different from individual SA because they are all interconnected, each of them is based not only on individual acts, but necessarily takes into account the supposed future acts of all other mutual activity realization of the acts of its individual participant is regulated both by the reflection of the object it is aimed at but also the actions performed by other participants, and those changes in the object which are the result of it. The acts of an individual are thus built not only in accordance with the correspondence to the task and object. The individual, participating in activity, "adapts" the action performed by other people. The regulation of an individual act includes the moment of "adaptation". It makes such characteristics of action as "dynamics" more intensive. Finally, the evaluation of result complies with the demands that are determined by agreement of "mutuality" of joint activities. [13; 235-236]. Consequently, the content of SA in joint activities is richer than the content of individual SA in person-to-person communication, as each of the participants uses in them information, which couldn't be gained without communication in collective, not using the experience of other participants of joint activity.

\section{Functions of communication}

Another aspect of our research is the study of functions of communication. It will help to present the planned result of schooling as an ability to realize the main functions of communication. In communication theory the following functions are distinguished: informational-communicative, regulatory-communicative, affective-communicative. In Methods of Teaching Foreign languages these functions were defined by I.L, Bam as cognitive, regulative, value-orientation, conventional [3]. We will base our research on this classification as it gives the possibility to present the planned results of training. This distinction is purely theoretical, as all these functions are interconnected with each other in real-life communication. Under cognitive function we mean the processes of transfer and acceptance of information. It is in this or that way connected with people's activities oriented in conditions and means of its realization. Even thinking processes proceed faster under condition of constant informational communication. 


\section{Changes in the category "the choice of content of philologists training"}

For students the realization of their cognitive function is correlated with their studies and can be successful, if they pass credits, examinations, defend course and diploma papers. In Kahoot it is represented as the idea of "collaborative learning", the importance of social interaction, teacher's active role in students learning (as a like-minded), zone of proximal development and significant others (students at different levels helping each other out). Another function is regulatory-communicative. It is realized in the process of student's own behavior and the other people's behavior. "In the process of communication an individual can influence the motive, aim, program, decision-taking, execution of several acts and their control, i.e. on all components of his partner's activities. In this process mutual stimulation and correction of behavior is realized. This influence can be very deep and influence a personality as a whole [25; 229]. Regulative function can perform in the form of call to action or end of action. Recommendation, appeal, order, motto is the example of it. Its meanings are known to everyone since childhood. The regulative function is also realized in the form of interdiction. The first thing a small child understands is impossible and possible. Interdictions play an important role during the life of people. Much in their future life will depend upon how well students have understood social interdictions. Interdictions in Kahoot are only represented as possible. Very special is the third realization of regulative function - destabilization. It was created in the history of civilization. A man was doing his work in favor or against people. This function is now realized in everyday life in the form of reproach, threat and damnation. We can find connections between many of these concepts in Kahoot "Learners to Leaders" model. "Both when it comes to students collaborating on creating cahoots, and when students take action and lead their classmates through a game. social interaction plays a great part in our cognitive development. Or, if we put it into simpler words - we learn better and get more motivated when we learn together" $[7,8]$. In creating cahoots the third realization of regulatory function is not taken into account.

The third function is value-orientation one. It is connected with the desire to communicate with friends, maintain friendly relationship, based on mutual interests, joint activities. It is very well provided in Kahoot.

The fourth function is conventional. It is realized according to the norms of behavior, accepted in society a student lives in and those in the English-speaking countries. This function can also be realized in Kahoot. 
Under certain conditions one of the functions can become the leading one. For example, in conditions of joint activity regulative function is the leading one. It reflects the active position of communicators, their intention to influence others with the aim of changing their actions, plans and can be realized in the form of call to actions, interdiction of actions, organization of joint actions, correction of actions of other participants and so on. Exchange of information in the process of joint activities directly or via social nets, evaluation of its results is finally oriented on getting regulatory effect. In Kahoot these joint activities are aimed at learning. "Today, the greatest challenges to people realizing their deepest potential aren't just outdated curriculums or class work; it's the learning experience itself' [7].

\section{Speech forms}

The third characteristics of communication is closely connected with the first two ones. Thus, for socially-oriented communication the most typical speech forms are extended monologues and for person-to-person communication - a dialogue, for group communication - a group dialogue (polylogue). Dialogues and monologues are classified by scientists on the basis of such principles as psychological attitude of the speakers on information exchange, expression of attitude to the subject of speech and the partner, regulative effect [13]. Correspondingly they name the following types of dialogues: 1) one-sided regulative dialogue, 2) one-sided message giving dialogue,3) dialogue of reciprocal information exchange, 4) reciprocal regulative dialogue,4) exchange of impressions dialogue, 5) dialogue-dispute [10]. According to N. F. Borisko there are the following types of monologues:1.informative (information, report, description, thesis, narration, image...); 2.activating monologue (request, demand, invitation, order, praise, reprimand, permission, prohibition, persuasion, obligation);3. explaining (explanation, reasoning, proof, disproof, definition, generalization, comparison); 4.establishing contacts (greeting, leave taking, introducing, opening, congratulation, invitation, refusal) [2]. Types and kinds of dialogues are created in different kinds of communication. All of them exist in students' communication, but for scientific communication the most typical are dialogues of the 1,2 and 3 types and the 2 and 3 types of monologue. Thus, for socially-oriented communication the most typical speech forms are extended monologues and for person-to-person communication - a dialogue, for group communication - a group dialogue(polylogue). 


\section{Changes in the category "the choice of content of philologists training"}

\section{The micro(lowest) level of analysis}

The analysis on the micro level is connected with the distinction of elementary units of speech communication, coupled speech acts of partners in communication, forming a cycle, in other words one step acts of speech interaction. The analysis on this level is complicated by the absence of the unanimity as to the unit of communication, which cannot be subdivided further on, ways of its distinction. In most modern books speech act is mostly distinguished. For example, Kornayeva Z. V., who made an attempt to choose materials on the communicative basis, distinguishes speech act as a unit of communication including speaking of one partner and listening of another [11]. But such distinction gives only procedural characteristics. Act of person-to-person communicative interaction is one of the types in the cycle of dialogue communication in the act of interaction $[11 ; 11]$. M. M. Bakhtin also noted that the act of communication is not only speaking of one partner and listening of another. The listener has an active position, he either agrees or disagrees with the position of the speaker, adding to it $[1,246-247]$.

As we wanted to have a more detailed definition we found out many different terms such as «акт мовлення» (act of speech)," мовленнєва дія» (speech action)," мовний вчинок» (speech act). In some works, these terms are used as synonyms [28;3] or they are differentiated [5]. In spite of differences in definitions all of them recognize the subdivision of speech flow into segments. I. L. Bim writes that "the main constituent elements of speaking are acts of speech,(speech actions, acts), included into non-speech activity or resulting out of it" $[3 ; 20]$. In Linguistics the term was firstly used by L. Yelmslev, who understood it as an individual speech act.

In Psychology speech act is defined as morphological unit of activity, an act is a unit of behavior. This unit can be viewed as an action, which has its signifier and signified. A signifier is what a person wanted to express (wittingly or unwittingly) with his action. The signified is the form of action's realization. The synonymic usage of the terms is connected with the fact that they are difficult to delimit and very often one is defined through another.

In socio-linguistic works the term:" communicative act" is also often used because the subject of socio-linguistic research is not only linguistic qualities of an object but the connection of speech behavior with the structure of social interaction of communicators usually called 


\section{Rubinska Bronislava}

'speech act'. As communication is socio-psychological phenomenon its units must reflect such characteristic features as interaction and influence. These features are partially expressed in the definition given by M. F. Stronin. "Speech action is a unit of speech activity, representing speech act in the form of a phrase or superphrasal unity, having speech influence, directed at the change of certain state of things and gaining the aims which were set." [23, 25].

In Methods of Teaching foreign languages there were many other definitions of the term. Having examined many definitions we came to the conclusion that for the pedagogical process the definition must include the presence of indication on the product, the procedural side and conditions in which speech act takes place. Thus, we combined different definitions and got the following one:" The act of speech is the interaction (or influence) of the sender and recipient, the basis of which is the message, realized in conditions of a certain speech situation, demanding the usage of certain language means organized in a statement".

Acts of speech are characterized by different types of functional interconnection: 1. information conveyance - speech reaction on it; 2 . asking for information - speech reaction on it; 3 . motivation (request, proposal, advice) - speech reaction on it; [26]. The predominance of this or that interconnection is defined by the kinds and types of dialogues. In the dialogue of the regulative type the third type of functional interconnection dominates. It is realized as a reaction to motivation in the form of: a) telling information (expressing agreement, disagreement to take an offer, objection, expression of doubt); b) asking for additional information; c) counterproposal. Thus, on the micro level of communication analysis we can consider aim of communication as a system-forming characteristic of communication. The main idea in our research is the statement that the main problems of choice with communicative aim must be solved on the basis of studying utterance, but not a sentence, because it is meant for usage in speech.

\section{Example of construction of the choice of content of training in the program for training bachelors}

We would like to illustrate the example of construction of the choice of content of training in one part of the program for training bachelors, who study English and French as a second language. 


\section{Changes in the category "the choice of content of philologists training"}

\section{List of general and subject specific skills and competencies}

General competencies: ability to scientific-professional speech in foreign language; ability to use foreign language for contact and discursive field of interaction on the basis of culture and English-speaking and French-speaking nation (people); for communication in foreign language scientific and professional environments; for the presentation of scientific results in oral and written forms, for understanding of foreign academic and professional texts.

- ability to navigate the features of functioning of humanitarian sphere, existing and perspective directions of translation activity. The capacity for absorption of a multifunctional complex of knowledge, skills and attitudes required for personal development, social integration and employment;

- the ability to operate, based on ethical motives, to criticism and self-criticism;

- the ability to establish contact and build discourse field interaction on the basis of the English-speaking and French-speaking nation (people) culture and speech;

- understanding and awareness of diversity and picturality of the modern world; the ability to quickly and competently use in professional activities business Ukrainian;

- the ability to maintain your body and psyche in a satisfactory condition, develop the physical ability and develop the volitional qualities;

- the ability to update or to practice critical thinking combined with common sense, as well as the ability to find, process and analyze information from a variety of sources, logically and consistently present information (in oral and written forms); speak your mind and receive information from the interlocutor;

- possession of invariant representation of a professional component directly, i.e. knowledge, skills, experience, values and attitudes, linguistic competence; willingness to provide the process of translation activities with relevant educational and methodical documentation and innovative projects;

- the ability to navigate the peculiarities of cultural and religious traditions, their language inherent to the English and the French-speaking ethnos (nation) and the people of the world, the ability to maintain an atmosphere of understanding; 


\section{Rubinska Bronislava}

- the ability to proficiently and terminologically correctly use original maxims in the process of professional and business communication;

- the ability to understand the basic mental processes and conditions that define the features of human activity, including the mental processes and realize focused adjusted impact on them;

- the ability to effectively apply in practice knowledge about the basic laws of functioning of society and the basic techniques and methodology of sociometrical research;

- the ability to identify, formulate and solve problems.

Subject specific skills and competencies:

- the complexity in the conduct of research in the humanities;

- he ability to analyse linguistic studies processes and professionally evaluate the ethnogeography situation in the English-speaking and Francophone regions of the world, form a system view of the development of events in different regions and countries, and to develop projects, aimed at achieving the objectives of the adequacy of the translation of these processes taking them into account;

- the ability to think globally, to act in a specific way according to the revealed situation of communication in the English-speaking and French-speaking region or country, using phono stylistic, stylistic, lexical-grammatical means, inherent in this region or country;

- the ability to apply research strategies in practice, to choose and effectively use those or other methods and methodologies of scientific research;

- the ability to understand the specifics of the specialty 'Philology' in general, to define the basic concepts and principles of the functioning of the language and speech system;

- awareness and ability to apply in practice rules and regulations for translating and ethics;

- the ability to be engaged as critical analyzer in a dialogue. The ability to participate in scientific discussions at the international level, defend their own position.

- the ability to acquire and operate key information on new educational standards based on, but not limited to, 'Recommendations of the European Parliament and the Council of Europe on the development of key competences for lifelong education' [20];

- the ability to navigate in the peculiarities of managing the educational process, the psychology of group dynamics, etc.; 


\section{Changes in the category "the choice of content of philologists training"}

- the ability to establish contact and establish a discursive field of interaction on the basis of culture and speech of a particular ethnic group (people), expanding operational linguistic capabilities;

- mastering of the system of knowledge about the specifics and methodology of pedagogical research and the formation of detailed knowledge about the object and subject of research;

- the ability to understand the current state and trends of global communication processes, forms and functions of communication to determine their impact on changes in the language and speech system, research and forecasting of the problems of the international community in the field of information and communication;

- the ability to use the provisions of domestic and international law, to adhere to the standards of participants in international communication;

-the ability to observe and analyze the educational work carried out with children and adolescents, competence in the system of educational work with students, the ability to conduct lessons using modern methods and techniques of educational and cognitive activity;

- the ability to operate the knowledge of the basics of modern translation science on the expert level;

- competence in the field of educational institutions and organizations, peculiarities of their functioning and calling;

- the ability to carry out educational work with children on the basis of studying a foreign language, taking into account age and individual characteristics;

- the ability to use dictionaries, terminology Standard, collections, reference books and manuals;

- the ability to prepare abstracts and thesis of foreign literature and scientific and technical documentation;

- the ability to use information and technology competence, that is, having knowledge and related skills of working with certain equipment (microphones, headphones, consoles for simultaneous interpretation, receivers and transmitters, sound system and conference system, in the case of interpretation);

- the ability to have information and technological competence, that is, the ability to work with a package of special-purpose office programs and specialized software for translator;

- possession of knowledge on the history of methods of teaching foreign languages and the ability to use advanced pedagogical experience of the past; 


\section{Rubinska Bronislava}

- the ability to understand the peculiarities of the organization of the living and cultural space of the English-speaking and French-speaking ethnic groups and the interaction between them;

- the ability to carry out self-monitoring, self-examination and objective self-assessment of their pedagogical activity;

- the ability to navigate in pedagogical institutes, processes and phenomena, to understand their essence.

\section{Conclusions}

The analysis of the category" contents of training' has shown that it has changed under the influence of new technologies and communication theory development. New principles of self-guided, inquiry-based learning and integration have been added. The category "construction of content of training of foreign languages", which is aimed at peculiarities of communication has also changed, which surely corresponds to the demands of modern society. We investigated not only general problems of communication but also communication of students, who study at the humanities department. We have analyzed their communication on three levels: highest (macro), medium (mezzo) and lowest (micro). Such approach allowed us to consider students 'activities on the level of activity, detailed actions and separate associated actions, to find out their immanent characteristics and advance to the new elements in the content of training. This category is closely connected with another category "content of education", the inalienable part of which is the choice of the philologist's content of training on the basis of activities and competency-oriented approach. Many researchers think that the idea of competency is the idea of an open order on content of education. We clarified and specified this category from the positions of educational activity that involves student's collaboration and creative activities. Modern educational platform Kahoot integrated together the concept 'content of training and "methods of teaching based on gaming", added two principles of the choice what to teach: self-guided and inquiry-based learning. There are still more elements that should be included into this concept. They are: the profile and the set of subject specific and generic competencies that constitute the program level outcomes. The" profile" is what the graduate students know and are able to do, having the potential school director who will hire them, in mind. The list of these competencies based on our analysis of students' communication on three levels illustrates the results of the choice. 


\section{Changes in the category "the choice of content of philologists training"}

\section{References:}

1. Bakhtin, M. M. (1979). Estetyka yazykovogo tvorchestva [Esthetics of Verbal Creativity] collection of selected works. Moscow: Art. (in Russian).

2. Balayan, A.R. (1971). Osnovnye komunikativnye kharakterystiki dialoga [The Main Communicative Characteristics of a Dialogue] $(\mathrm{PhD}$ thesis in Philological Science), Moscow: Moscow State University. (in Russian).

3.Bim, I. L. (1979). Nekotorye problemy obuchenya dialogitsheskoy rechi [Some Problems of Teaching Dialogue Speech.], Foreign Languages at School. № 5, pp.20-27. (in Russian).

4.Borisko, N.F. (1987). Obutshenye monologitsheskoy rechi $s$ ispolzovanyem videofonogram [Teaching Oral Monologue Speech with the Usage of Videophonogramma at the Beginning stage of Language Higher Educational Establishment in the Intensive Course (on the material of the German Language $(\mathrm{PhD}$ dissertation in Pedagogical Science), Kyiv: Kyiv Institute of Foreign Languages. (in Russian).

5. Doroshenko, A.V. (1986) Pobuditelnye akty rechi $i$ yih interpretatsya $v$ teksti (Incentive Speech Acts and their Interpretation in the Text (on the Material of the English Language) (PhD thesis in Philological Science), M.: Moscow Institute of Foreign Languages. (in Russian).

6. Fastovets, R.V. (1985). Metodyka obutshenya ustnomy inoyazytshnomu obshcheniyu na natshalnom etape $v$ yazykovom vuze (na materyale angliyskogo yazyka). [Methods of Teaching Oral Foreign Language Communication at the Beginning Stage in a Language University (on the material of the English Language)] ( $\mathrm{PhD}$ dissertation in Pedagogical Science), Kyiv: Kyiv Institute of Foreign Languages. (in Russian).

7. Some tips for your academic research - Kahoot! Support kahoot. Available at: - uservoice.com/knowledgebase/les/. (accessed 3 times in January)

8. Kahoot - Online Tools for Teaching \& Learning. Available at: blogs.umass. eduarti (accessed 3 times in January)

9. Karimova L.A. (2009). Soderzhanye $i$ metodyki obutshenya inostrannym yazykam $v$ uslovyah modernyzatsyi vysshego professionalnogo obrazovanya na prymere tehnytsheskih vuzov - utschastnikov bolonskogo protsessa [Contents and Technologies of Teaching Foreign Languages in Conditions of Modernization of Higher Professional School: on the Example of Non-humanities Profile Universities - Participants of the Bologna Process] (PhD thesis. in Pedagogical Science), Kazan. Available at: 9 http://www.disserca (in Russian).

10. Klimentenko A. D, Vaisburd, M.L. and als. (1984). Soderzhanye obutshenya inostrannym yazykam $v$ shkole: organizatsya retchevoi deyatelnosty. [Contents of Teaching Foreign Languages at School: Organization of Speech Activity].M:Pedagogics. (in Russian). (in Russian).

11. Kornayeva Z. V (1982). Organyzatsya obutshenya dialogitsheskoi retshi $v$ 4-5 klasah sredney shkoly ( na materiali nemetskogo yazyka) [Organization of Teaching Dialogue Speech in the 4-5 Forms of a Secondary School (on the material of the German Language)] ( $\mathrm{PhD}$ dissertation. in Pedagogical Science). M: Moscow Institute of Foreign Languages. (in Russian).

12. Leontyev A. A. (1979). Pedagogytsheskoye obshchenye [Pedagogical Communication]. M: Knowledge. (in Russian). 


\section{Rubinska Bronislava}

13. Lomov B. F. (1984). Metodologytsheskie i teoretytsheskie problemy psyhologyi: monografia [Methodological and theoretical problems of Psychology: monograph]. M: Science. (in Russian).

14 Malihin O. V. (2014) Ierarhiya kompetentnostey suchasnogo pedagoga [Interactive competency of a modern specialist in Pedagogics] Proceedings of the 1025-richchya Istoriy i osviti v Ukrayini: trudnoschi, suchasnist ta perspektivi : zb materialIv mizhnar. nauk. konf. (Ukraine, Kiyiv.NUBiP,pp. 65-75.(in Ukrainian).

15. Mironova T.Y. (1985). Obuchenye ustnoy ekspressivnoy retchy $v$ intensivnomu kursi inozemnoy movy (Problemy soderzhanya obutchenya) [Teaching Oral Expressive Speech in the Intensive Course of a Foreign Language (Problems of the Contents of Teaching)] ( $\mathrm{PhD}$ dissertation of Pedagogical Science).M: Moscow Institute of Foreign Languages. (in Russian).

16. Manko Y. N. (1979). K voprosu ob urovnevom analize sotsialnogo vozdeystvia na formirovaniye zhiznennoy pozitsyi [To the Question of Level Analysis of Social Influence on the Formation of Socially Active Position of a Pupil.Problems of Psychological Influence] interuniversity collection of scientific papers. Ivanovo. Ivanovo State University of the First in Russia Ivanovo-Voznesensky City-wide Soviet of Workers' Deputies, pp. 30 - 40. (in Russian).

17. Modern Methods of Teaching Foreign Languages at School: Textbook for Teachers. (2003) ISBN 5894152909 2003, М: АРКТИ. Available at: http://refleader.ru/jgemerqasjgebew.html.

18.Pak M. S. (2015) Problema yntehratsyy obrazovanyia y nauky. [The problem of integration of education into science],K: VYShchA OSVITA UKRAINY: Teoretychnyi ta naukovo-metodychnyi chasopys., vol. № 3 .

Dodatok 1: Intehratsiia vyshchoi osvity i nauky. Kyiv: Instytut vyshchoi osvity NAPN Ukrainy.pp.189-190. (in Russian).

19.Passov Y.I. (1980). Opredelenye ponyatia "komunikativny metod" [The Definition of the notion "communicative method"]: Voronezh State Pedagogical Institute. vol. 208. pp. 26 - 39. Problems of Communicative Teaching of Foreign Language Activity: a collection of articles. Voronezh: News (in Russian).

20. Rekomendatsiia 2006/962/IeS Yevropeiskoho Parlamentu ta Rady (IeS) Pro osnovni kompetentsii dlia navchannia protiahom usoho zhyttia" vid 18 hrudnia 2006 roku. Available at: http://zakon2.rada.gov.ua/laws/show/994_9752. http://osvita.ua/legislation/law/2231/_2006.pdf. (in Ukrainian).

21. Rubinska B. I. (2013). Diiānnisni kharakterystyky spilkuvannia studentiv:vyshchyi riven analizu [Activities Approach of Students' Communication]. Problemy osvity,vyp. 74. Ch. I, Kyiv, pp. 235 -236. (in Ukrainian).

22. Skalkin, V. L. (1983). Situatsia, tema i tekst v lingvometodologytshnomu aspekti;(organyzatsya materyala dlya ustnoy retshy) [Situation, Theme and Text in Linguistic-methodological Aspect; (Organization of Material for Oral Speech)]. Russian Language Abroad, 3. pp. 52-58. (in Russian).

23. Stronin M. F. (1985). Akt retshy kak osnova obutshenya ustnoy inoyazytshnoy retshy (na material shkol s obutsheniem ryada predmetov na angliyskom yazyke. [Speech Act as the Basis of Teaching Oral Communication.(based on the material of schools with teaching some subjects in English)] ( $\mathrm{PhD}$ dissertation in Pedagogical Sc.), M:The Academy of Pedagogical Science of the USSR. (in Russian). 


\section{Changes in the category "the choice of content of philologists training"}

24. TUNING Educational Structures in Europe II Universities' contribution to the Bologna Process. University of Deusto, University of Groningen. Available at: 386p.nzydpu_pp_2011_34_28.

25. Vaisburd M. L. (1981). Typologya utshebno-retshevyh situatsyi [Typology of Teaching-Speech Situations]. Psychological-pedagogical Problems of Teaching Foreign Languages: a collection of scientific papers/edited by A. D. Klimentenko, O. I. Moskalska M: Research Institute of Contents and Methods of Teaching of the Academy of Pedagogical Science of the USSR]. pp. 81-91. (in Russian).

26. Yudin Y. E. (1981). Pro rol obutshenya retshevym situatsiam [On the Role of Teaching Speech Situations.] Psychological-pedagogical Problems of Intensive Teaching of Foreign Languages: collection of scientific papers. / edited by A.D. Klimentenko, O.I. Moskalska. Moscow: The APS of the USSR, ScientificResearch Institute of Contents and Methods of Teaching. p. 29 (in Russian).

27. Zakon Ukrainy "Pro osvitu" (Pryiniattia vid 05.09.2017. Nabrannia chynnosti 28.09.2017) Available at: http://zakon2.rada.gov.ua/laws/show/2145-19_2017.pdf.

28. Zhdanko O.I. (2011) Otbor I organizatsya soderzhanya obutshenya profesionalno-napravlennoy lexike dlia studentov institute tehnologyi. [Selection and Organization of Teaching Content of the Professionally Oriented Lexis for the Students of the Institute of Technology.] Calculations Technique and Engineering Education. no. 12 (4). Available at: Digital-magtti.study.ru>lib/4/5-2011-2(4) pdf. (in Ukrainian). 